\title{
DWPF Welder Parametric Study
}

by

M. J. Plodinec

Westinghouse Savannah River Company

Savannah River Site

Aiken, South Carolina 29808

J. R. Harbour

DOE. Contract No. DE-AC09-89SR18035

This paper was prepared in connection with work done under the above contract number with the U.S. Department of Energy. By acceptance of this paper, the publisher and/or recipient acknowledges the U.S. Government's right to retain a nonexclusive, royalty-free license in and to any copyright covering this paper, along with the right to reproduce and to authorize others to reproduce all or part of the copyrighted paper. 


\section{DISCLAIMER}

This report was prepared as an account of work sponsored by an agency of the United States Government. Neither the United States Government nor any agency thereof, nor any of their employees, makes any warranty, express or implied, or assumes any legal liability or responsibility for the accuracy, completeness, or usefulness of any information, apparatus, product, or process disclosed, or represents that its use would not infringe privately owned rights. Reference herein to any specific commercial product, process, or service by trade name, trademark, manufacturer, or otherwise does not necessarily constitute or imply its endorsement, recommendation, or favoring by the United States Government or any agency thereof. The views and opinions of authors expressed herein do not necessarily state or reflect those of the United States Government or any agency thereof.

This report has been reproduced directly from the best available copy.

Available to DOE and DOE contractors from the Office of Scientific and Technical Information, P.O. Box 62, Oak Ridge, TN 37831; prices available from (615) 576-8401.

Available to the public from the National Technical Information Service, U.S. Department of Commerce, 5285 Port Royal Road, Springfield, VA 22161. 


\section{DISCLAIMER}

Portions of this document may be illegible in electronic image products. Images are produced from the best available original document. 
Reywords: DWPF, canister, upset resistance welding

August 21, 1995

TO:

E. W. HOLTZSCHEITER, 773-A

FROM :

B. J. EBERHARD, J. R. HARBOUR, M. J. PLODINEC

$$
\text { onn }
$$<smiles></smiles>

DWPE WELDER PARAMBTRIC STUDY (U)

CC:
E. F. Duhn, 773-A
M. K. Andrews, 773-A
D. C. Beam, 773-A
N. E. Bibler, 773-A
D. F. Bickford, 773-A
C. A, Cicero, 773-41A
D. M. Ferrara, 773-A
B. C. Ha, 773-A
D. T. Herman, 773-41A
C. M. Jantzen, 773-A
A. L. Kielpinski, 773-41A
R. E. Mottel, 773-43A
W. G. Ramsey, 704-1T
R. F. Schumacher, 773-41A
D. A. Crowley, 773-23A
L. F . Landon, 704-T
C. T, Randal1, 704-T
GTG FILES
TIM, 773-52A

\author{
S. F, Piccolo, 704-S \\ J. W. Wilson, 210-S \\ J. T. Carter, 704-25S \\ W. D. Kerley, 704-26s \\ H. H. Elder, 704-S \\ J. F, Ortaldo, 704-S \\ D. C. Iverson, 704-25s \\ J. F. Sproull, 704-16S \\ S. L. Marra, 704-25s \\ P. D. Hughes, 704-26s
}




\section{INTRODUCTION AND SUNAARY}

After being filled with glass, DWPF canistered waste forms will be welded closed using an upset resistance welding process. This final closure weld must be leaktight, 1 and must remain so during extended storage at SRS.

As part of the DWPF startup Test Program, a parametric study (DWPE-WP-24) has been performed to determine a range of welder operating parameters which will produce acceptable welds. The parametric window of acceptable welds defined by this study is $90,000 \pm 15,000 \mathrm{lb}$ of force, $248,000 \pm 22,000$ amps of current, and $95 \pm 15$ cycles $^{\star}$ for the time of application of the current.

Based on this study, a set of conditions is recommended for preparing welds for qualification of the welding system (machine, weld procedure, and welding operators). Welder settings of 677 psig for the initial welder force setting, 62 Heat for the welder current setting, and 95 cycles of $60 \mathrm{~Hz}$ current should reliably produce acceptable welds. These values correspond to a force of $80,000 \mathrm{lb}$ and a maximum current of 248,000 amps. This force is set below the median force of the parametric window, in order to optimize the strength properties of the final weld.

\section{RROCESS AND EODIRMENT}

Upset resistance welding has been used extensively at SRS since 1967. This process was chosen as the method for canister closure in 1979, based on the simplicity of the process, and the ease and reliability of process control (from prior SRS experience with this process) .2 .3 The present DWPF welding process is the result of an extensive development effort carried out at TNX.3

After decontamination and drying, a canister is moved to the weld Test cell for final closure. The Inner Canister closure (ICC) is pushed down into the canister neck, exposing clean metal for a permanent plug weld. The $12.7 \mathrm{~cm}$ plug, which is slightly larger in diameter than the nozzle bore and has a chamfered edge, is centered in the nozzle. The canister is supported by its flange on the welder bottom electrode, then the upper electrode is lowered onto the plug. This electrode serves as the upper platen applying force to the weld plug.

The operator sets the initial force applied to the weld plug by opening an air valve. The valve is marked in pounds per square inch of air pressure, rather than force. As force is applied to the plug, a large amount of direct current is passed through the

*In this report, time of application of current is reported as cycles of $60 \mathrm{~Hz}$ current. 
plug and nozzle. The operator sets the amount of current on the welder controller, in units of "o Heat."

The $40 \mathrm{~cm}$ line of contact is heated (but not melted), the plug is forced into the nozzle, and a $1-\mathrm{cm}$ thick, solid state weld is made in less than two seconds. The weld produced is sufficiently leaktight to meet the WAPS (Waste Acceptance Product Specifications) specification (based on experimental evidence, the weld is leaktight to approximately $1 \times 10^{-9} \mathrm{~atm}-\mathrm{Cc} \mathrm{He} / \mathrm{sec}$, and of comparable strength to the base metal3).

Although the operator sets the initial force, the "q Heat" setting, and the time of application of the current, the variables which actually determine weld quality ${ }^{3}$ are the actual force applied to the weld plug by the upper electrode, the maximum current achieved during the welding process, and the time during which the current is applied (preferably expressed as cycles of $60 \mathrm{~Hz}$ current - the indicated number of cycles corresponds exactly to what is delivered by the welding machined). As will be discussed later, the initial force setting and the "f Heat" are directly proportional to the actual force applied and the maximum current, respectively.

The DWPF canister welder, located in the Weld Cell of 221-s, was used for making the welds for this test. It was fabricated by Newcor of Bay City, Michigan. This machine was designed to deliver a maximum of $400 \mathrm{kA}$ of direct current from four $100 \mathrm{kA}$ rectifiers located outside the Weld cell. The direct current is delivered to the weldment through four sets of 35 feet bus bars. The welding machine is a pneumatically-operated four post press in which the ram and the lower platen also serve as the upper and lower electrodes, respectively.

All welds for this study were made using threaded canister nozzles containing an ICC plug and sleeve. The nozzle was screwed onto a reusable, glass-filled canister body. The nozzle-canister body assembly is geometrically and electrically equivalent to an actual canister. The nozzles and plugs were purchased to procurement specification $M-356$ on purchase requisition MH-23030 (This specified the use of Lava $A$ for the ceramic rings for the weld plugs. Since that time, Lava A has been superseded by other materials). The nozzles (Part No, 839376-A) were fabricated using ASTM-A336 304-I stainless steel forgings, and the weld plugs (Part No. 199208-A) were machined from ASTM-A240 304-L stainless steel plate. The power pack current sensors, the load cell sensor for measurement of force, and the timing sensor were all in calibration and traceable to NIST standards. All welds were made in accordance with equipment operating procedures, including push-in of the ICC plug by the hydraulic ram. 


\section{HELD ACCEPTABTI ITY CRITRRIA AND RARAVETRIC HINDOW}

According to the WAPS, 1 the final weld closure must be leaktight (1 $\times 10^{-4}$ atm-cc He/sec). Thus, this leak rate constitutes the major criterion for weld acceptability. However, in order to assure overall weld quality, and thus the ability of the weld to remain leaktight during extended storage at SRS, several other criteria were also applied to the welds produced during the parametric study. 5

- The final weld closure must be leaktight to $1 \times 10^{-7}$ atm-cc He/sec at $25^{\circ} \mathrm{C}$. This means that the weld is not only water-tight, but gas-tight as well, providing a measure of conservatism to the leaktightness measurement.

- The burst strength of the welded flange assembly must be greater than or equal to the burst strength of the canister 12600 psig). In conjunction with the next criterion, this ensures that the weld itself does not contribute to a premature failure of the canister closure.

- The tensile strength of the weld must be greater than or equal to $75,000 \mathrm{psi}$ (the tensile strength of annealed $304 \mathrm{~L}$ stainless steel, i.e., the canister wall itself).

- Bend test specimens from the weld must have no defects greater than 0.125 in. when tested according to ASME B\&PV Code, section IX, QW-160. This criterion, in conjunction with the next one, was intended to ensure that there were no hidden flaws in the weld which might compromise its integrity in case it was bumped or dropped, and to ensure the ductility of the weldment metal. As is discussed below, after Part $A$, the bend test was replaced by a Eracture test. The same criterion applied to the fracture test. specimens.

- The bonded interface ("weld throat") distance must be equal to or greater than the minimum thickness of the canister wall 10.335 in). There must be no flaws at the weld interface.

The objective of startup Test 24.01 was to identify bounding values of the welding parameters (the parametric window) which met two acceptance criteria:

(1) All welds produced within the parametric window had to meet all of the weld acceptability criteria above.

(2) The width of the parametric window had to be at least six times greater than the standard deviation of each operating value.

\section{GXPRETMEANAT, PTAN}

The welder parametric study was divided into three parts. The values of the key welding parameters - the initial force, the 
maximum direct current, and the time of application of current for each part of the study are shown pictorially in Figure 1 . The target and actual values for all welds are given in Tables 1 - 3 .

Part A was a preliminary study which used a wide range of the key parameters. It was intended to identify a region of weld acceptability to be used to define the parametric window. The values used were based on data from about a dozen welds made during acceptance testing of the welder at the vendor in $1987-88$. It was not necessary that all of the Part $A$ welds be acceptable; only that a region of weld acceptability be identified for subsequent testing.

In fact, several of the welds produced during Part A did not satisfy the criteria for weld acceptability described above which made it difficult to determine a suitable region for the weld parametric window. For this reason, Part $B$ was undertaken. Part $B$ consisted of five additional welds, and was intended to explore the effects of higher forces or times on weld acceptability, to better identify the target region for the parametric window. Because Part $B$ was essentially a scoping activity, these welds were evaluated only in terms of the most important criteria (leak rate, burst strength). Some of the part $B$ welds also did not satisfy the weld acceptability criteria.

Based on the results from parts $A$ and $B$, a likely region of acceptable welds was identified for part $C$. As can be seen in Figure 1, the Part C conditions lie entirely inside the set of conditions tested in parts $A$ and $B$. Part $C$ of this study was initiated to identify the parametric window of acceptable welds, i.e.. all of the part $C$ welds were expected to be acceptable. As is discussed in the "Results" section. Part $C$ met this objective, and satisfied the breadth criterion for the parametric window as well. Thus, the conditions used for part $c$ defined the parametric window called for by the WP-24 Test plan.

\section{PGELD SPBCIMEN BVALUATION METHODS}

Leak Rate Test: All welds were tested for leak tightness using a mass spectrometer detection system following EMT Field Procedures FP-295 and L9.4-8303.6

Plug Height Measurements: All welds from this study were measured for post weld plug height using EMT Field Procedure FP-441. This testing was performed under the supervision of Equipment Engineering section of SRTC. 6

Burst Test: Welds which were to be burst tested had a hole between $5 / 16$ and $3 / 8$ inch drilled through the ICC plug. A specimen was then formed by welding a cup onto the nozzle according to Drawing EES-91054-R4-013, Rev. A. Burst tests were then performed according to EMT field procedure FP 424 , Rev. 1.6 
Specimen Preparation: The sectioning, identification and machining of test specimens was done in accordance with the drawings provided in reference 6 and EMT Field Procedure FP-423. Each weld from Part $A$ and those from Part $C$ that were not hydrostatically burst tested (Ref EMT Field Procedure FP-424), were cut and identified according to drawings EES-911054-R4-009 and -014. Tensile specimens and bend specimens were machined from all the welds of Part A. Tensile specimens were also machined from selected welds of Part C.6

Tensile Test: Tensile testing was conducted by Reactor Materials Quality-Metallurgical Laboratory in accordance with their procedures SOP 322-1-306 and SOP 322-77T. ${ }^{6}$

Bend Test: The bend test (EMT Field Procedure FP-415) was only used in Part A of this study, 6,7 based on a recommendation from Equipment Engineering section. As noted above, the purpose of performing this test was to determine the ductility of the weldment metal, and to highlight any flaws. It was not used in the evaluation of the welds from Parts $B$ and $C$ for the following reasons:

- Preparation of samples for testing was difficult, timeconsuming, and expensive. The bend test requires removal of both the top and bottom crevices of the weld (see Pigure 2). to avoid a notch which could affect the results. These crevices axe difficult to see on the machined specimen, and their removal requires repeated dye penetrant testing. - The reproducibility of the results was poor. As can be seen in Table 3, for four of the nine samples, one specimen failed the test, and one passed. Thus, unambiguous results were not readily obtained. - Many of the samples broke during testing, complicating interpretation of the results. This is most likely due to the unfavorable geometry (two independent nonlinearities in the weld region of the specimens). It should be noted that the bend test is not a requirement for acceptance of resistance welds in section IX of the ASME Boiler and Pressure Vessel Code.

- Bend testing had never been done before on this type of weld. Thus, there was no baseline established for comparison of the results to previous work.

- The simple fracture test described below gave the same information on metal ductility more reproducibly, and without the exacting sample preparation process.

- The tensile strength test and the burst test yielded quantitative information on weld strength, compared to the qualitative "pass/fail" of the bend test.

This substitution was reviewed and approved by both SRTC and DWPF Process Engineering prior to performance of Part $c$. 
Fracture Test: This test was used in place of the bend test for welds produced in Part $\mathrm{C}$ of this study. Fracture specimens were pie-shaped sections. The pointed end of this specimen was clamped in a vise and the other end pounded over with a sledge hammer until the weld broke. ${ }^{6}$ As noted above, the results from this test were more repxoducible than those from the bend test.

Metallographic Examination: Two metallographic specimens were examined from each weld of Part $A$ and all 24 welds of Part $C$ that were not burst tested. These were used to measure weld throat thickness and crevice length (the amount of unwelded interface) and to assess the metallurgical structure of the weld zone. Weld throat is defined as the minimum distance through the weld region from the inside of the canister to the outside environment (see Figure 2). Evaluation and analysis of the weld microstructure was carried out by the Materials Technology section of SRTC. ${ }^{B}$

\section{RESUTHS: PARTA A}

Part A was a preliminary study using nine welds made under conditions at the eight corners and center of a cube. This cube was defined by the values of applied force, the maximum direct current applied, and the time of application of current listed in Table 1. As noted in the "Experimental Plan," the purpose of this part of the study was to identify a region where acceptable welds could be made. 1.e., all of the welds for Part $A$ were not required to be acceptable.

Weld evaluation was carried out using the methods described above. The results are presented in Table 4 . All of the welds satisfied the leak rate criterion. However, seven of the nine welds failed at least one of the other weld acceptability criteria. Three of the welds failed the tensile test criterion; each of these welds failed in the weld rather than the base metal. Only two of the samples passed the bend test; the other seven fractured while being bent. Two of the four welds made at 45 cycles failed the weld throat distance criterion; they were the only ones to fail this criterion. The data also show that plug height is a good indicator of weld strength - welds for which the plug height exceeded $90 \mathrm{mils}$ failed the tensile strength test.

\section{RESULTS: PART B}

As noted above, the results of Part $A$ were disappointing in that so few of the welds were acceptable. Part B explored more extreme conditions within the parameter space, in order to indicate the likely direction of the final window. Part $B$ of the parametric study was thus composed of five welds. These were made at values of force, current, and time of application of current listed in Table 2. These welds were evaluated only by burst strength and leaktightness: the results are presented in Table 5 . As in Part A, all of the welds passed the leaktightness criterion. The three welds which did not satisfy the burst strength criterion were all 
made at short times ( $\leq 65 \mathrm{cycles}$ ). Again, plug height was indicative of weld strength (here measured by burst strength): the unacceptable welds all had plug heights in excess of $150 \mathrm{mils}$.

\section{RESULTS: PART C}

Taken together, the results of parts $A$ and $B$ indicated that the region most likely to produce acceptable welds would be shifted toward the highest current values used in part $A$, and away from short weld times ( 45 cycles). It was also clear from the results of Parts $A$ and $B$ that $a$ more limiting set of parameters was needed for Part $C$. Due to the time constraints imposed by the DWPF schedule, and the high cost of these tests, a rather conservative parameter space for Part $C$ was selected. The goal was to select a parameter space for which all welds satisfied the acceptance criteria. If successful, this would then define the parametric window of acceptable welds, and no additional welds would be required after part $c$. As discussed below, all of the Part $c$ welds satisfied all of the weld acceptability criteria, thus the goal was achieved.

Part $c$ was a replicated, central composite, three factor factorial experiment with face points to assess quadratic effects. Initially, thirty two welds were made using a target parameter range of $90 \pm 15 \mathrm{klb}$ initial force, $248 \pm 22 \mathrm{kA}$ maximum current, and 95 \pm 15 cycles (see Figure 1 and Table 3 ). After welds KS39 and KS40 were made, it was determined that the actual forces applied for these two welds were not very close to the target values. Thus, two more welds were made so that the desired values were more nearly achieved - KS39A and KS40A. At least two welds were made using the conditions at the vertices and the center of the cube. One set of these welds was used for measuring the burst strength while the other set was cut and machined for tensile and fracture tests, and metallographic examination. Weld evaluation was carried out as described above, with the fracture test being substituted for the bend test. The results for all thirty four welds are summarized in Table 6 , and are discussed below.

Leak Rate. All 34 welds (at 32 different points) made during Part $C$ of.this study showed no measurable leak rate, to the sensitivity of the leak rate equipment. This is approximately two orders of magnitude less than the acceptance criterion of $1 \times 10^{-7} \mathrm{~atm} \mathrm{cc} / \mathrm{sec}$ helium. Hence all welds readily satisfied this acceptance criterion.

Burst Test. Burst tests were conducted on 10 of the welds made in part $C$. These included all the vertices, the center of the cube, and one face point (KS25). The burst pressure values ranged from 5680 to 7100 psig (Table 6). The acceptance criterion for this test is 2600 psig and therefore all of the welds were acceptable.

Tensile Strength. The tensile strength of nine weld specimens were measured. These nine specimens included all the corners and 
the center of the cube. The values of the tensile strength ranged from 81,000 to 86,000 psi (Table 6). All welds satisfied the tensile strength weld acceptability criterion. Some of the welds broke in the base metal and some broke in the welded region.

Weld Throat Distance. The weld throat distance was measured on 24 welds (at 22 different points), and ranged from 0.376 to 0.427 inch (Table 6). All of these welds therefore satisfy the acceptance criterion for the weld throat distance ( 20.335 inch).

Eracture Test and Microstmucture. Metallographic examination of the fracture test specimens revealed that all fracture surfaces were ductile in nature. The only variation observed was in the texture. The majority of the welds were coarse ductile, with several medium ductile, and a few defined as fine ductile.6,8 Although there is no weld acceptability criterion for weld microstructure, weldments should be ductile in nature rather than

brittle. As-made weldments were also microstructurally examined.8 For all welds from Part $c$, the weldment had a weld throat distance in excess of the acceptance requirement, and were without voids or discontinuities. Thus, these acceptance requirements were satisfied.

Plug height ranged from 45 to $92 \mathrm{mils.} \mathrm{Although} \mathrm{no} \mathrm{acceptance}$ criterion exists for this value, it is a dimension that can be non-destructively measured on a canister. Hence, during radioactive operations, plug heights will be measured. If the plug height is less than or equal to $92 \mathrm{mils}$, this indicates that an acceptable weld has been made. If, in the future, welding parameter information is not available for a given weld, a plug height measurement will provide an excellent indication of weld acceptability.

These results demonstrate that all welds made in part $C$ are acceptable. Hence the welder parameter ranges of $90,000 \pm 15,000$ pounds of force, 248,000 $\pm 22,000$ amps of maximum current, and 95 \pm 15 cycles of $60 \mathrm{~Hz}$ current define a parametric window of conditions which will produce acceptable welds.

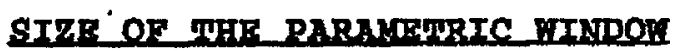

As noted above, the window of acceptable welds had to be at least \pm 3 standard deviations around the centroid, to satisfy the acceptance criterion for startup Test 24.01. A separate study had previously been performed to create seven welds as part of a test of ceramic ring materials.9 All of the welds were made under identical conditions, within the part $c$ window. The results of this study were used to determine whether the Part $C$ window was broad enough to satisfy the test's acceptance criterion.

The target values for these welds were 75,000 lbs initial force, 240.000 maximum amperage, and 90 cycles, which lie within the window defined by Part $c$. The first weld resulted in an initial 
force of 80,600 pounds. Rather than adjust the pressure regulator on the next welds to bring the force down to 75,000 pounds, the remaining six welds were made with the same settings for force. current and time. The results are shown in Table 7. The mean force was 81,100 pounds, ranging from 80,600 to 81,800 pounds, with a standard deviation of 400 pounds. The mean maximum current was $242 \mathrm{kA}$, ranging from 240 to $248 \mathrm{kA}$, with a standard deviation of $4 \mathrm{kA}$. As noted above, the number of cycles supplied by the welder is exact, i.e., there is no variability in the time of welding.

The force dimension of the parametric window of Part $C$ ranges from 75,000 to 105,000 , or 30,000 pounds. Hence, the parametric window of Part $C$ is much wider than six standard deviations $l=6 \times 400$ lbs) in terms of force.

For the current, the parametric window of Part $C$ of this study ranged from 226,000 to 270,000 amps. Hence, the parametric window of Part $C$ is much wider than six standard deviations $(=6 \times 4 \mathrm{kA}$ ) in terms of maximum current, as well (No correlation between the applied force and the maximum current was evident from this data.).

Thus, the parametric window used for Part $\mathrm{C}$ is more than wide enough to satisfy the acceptance criterion of startup Test 24.01 .

\section{QUATETY OF DAMA}

The parametric study incorporated a small amount of duplication of testing to provide insight into the reproducibility of the measurements (e.g., K27 and k39). The welds produced during the ceramic ring study were evaluated using the same quantitative methods as those used in this study (Table 8). Since several welds were made under identical conditions during the ceramic ring study, these results were used to quantitatively estimate the precision of the results reported here. Thus, taken together, these two sets of results can be used to indicate the quality of the results from the welds made during this study. The guality of the data from the parametric study appears to be consistent with that from the ceramic ring study.

All of the welds produced were below the detection limit for the leak rate instrumentation. This instrumentation was calibrated in accordance with site quality assurance procedures, and is traceable to the National Institute of standards and Technology. The burst strength results from the ceramic ring studies reveal that the burst pressures for four welds ranged from 6,500 to 7,500 psig (The 6,500 psig value appears to be an outlier with the other three values being much closer together). The standard deviation of these four values is $400 \mathrm{psig}$, corresponding to 5.6 \%RSD (relative standard deviation). This study did not duplicate the burst strength measurements, so there is no basis for comparison. 
The standard deviation of the tensile strengths of the ceramic ring welds is $2.7 \mathrm{kpsi}$, corresponding to $3.4 \mathrm{kRSD}$. Tensile strength measurements for samples KS40 and KS40A within this study agree within $2 \mathrm{kpsi}(-2 \%)$. Thus, the estimate of the precision of the tensile strength from the ceramic ring study appears to be consistent with the precision determined in this study.

The standard deviation of the plug height measurements of the ceramic ring samples is $1.5 \mathrm{mil}$ (corresponding to $1.8 \mathrm{gRSD}$ ). There are sixteen sets of replicate values of the plug height measurements in this study. KS01 and kS10 were duplicates of each other; and there are fifteen sets of replicates in part $C$. In each case, the standard deviation of the replicates was less than 3 rels, again consistent with the ceramic ring determination.

The standard deviation of the ceramic ring weld throat measurements was $10.5 \mathrm{mils}$ (corresponding to 2.6 \&RSD). There are seven sets of replicate weld throat distances, in Part $c$. All of them agree within 3 rel\%, again consistent with the ceramic ring results.

\section{MACHINB SBTTINGS AND CONDITIONS DURING MELDING}

As noted in the "Equipment" section, the operator of the welder sets an air pressure on a valve, a $\%$ Heat value on the instrument control panel, and the number of cycles to be applied. The values which control weld quality, however, are the actual force applied, the maximum current applied, and the time of application of the current.

The time of application of the current can be taken directly from the number of cycles set on the instrument. A setting of 95 cycles corresponds to 95 cycles/ $(60$ cycles/sec), or approximately 1.58 seconds. The force applied is also easily related to the initial force setting. The force applied is plotted as a function of the initial force setting in Figure 3 . The high value of $R^{2}$. 0.9992 , indicates that there is an excellent linear relationship between the two (For a perfect correlation, $R$ would equal \pm 1 ; for data which were completely uncorrelated, $R$ would equal 0.1 , and, as the figure shows, with almost no error.

The maximum current is also highly correlated with the "o Heat" setting $\left(R^{2}=0.9452\right)$. However, as Figure 4 shows, a given setting of "o Heat" may not always give the desired maximum current during welding. Thus, while the linear relationship shown in the Figure is useful for defining a trial setting to achieve a desired maximum current, tuning is necessary to determine a setting which will reliably provide the desired maximum current.

\section{PATH FORWARD}

The parametric study is only the first step on a path leading to qualification of the DWPF welding system (machine, procedures, and 
operators). Based on the results of this study, we recommend the following settings for use for welding system qualification during the DWPF Waste qualification Runs.

$\begin{array}{ll}\text { Force: } & 677 \mathrm{psig} \\ \text { \& Heat: } & 62 \% \\ \text { Time: } & 95 \text { cycles }\end{array}$

This set of welder settings is intended to provide an applied Force of $80 \mathrm{klbs}$, and a maximum current of $248 \mathrm{kA}$. We further recommend making a small number of welds under these conditions prior to the Qualification Runs to ensure that the settings identified above (particularly the 8 Heat setting) produce the desired weld conditions.

Although all of the welds made in Part $C$ are acceptable, they are certainly not equivalent. It is therefore important to select an operating location which will provide the best quality welds while not unnecessarily restricting the latitude of the operators. The conditions above have been recommended for the following reasons.

Burst strength. Burst strength is an excellent indicator of weld quality, and one that shows significant changes for welds made at various locations within the parametric window (Figure 5). Good burst strengths are obtained at lower force and lower levels of time and current. This trend is similar to data observed on earlier weld studies. Hence, these data suggest that the operating value for force should be near the low end of this parameter window. This is supported by the results of the ceramic ring study. These welds were made at a force level lower than the centroid of the parametric window. The burst strengths were among the highest obtained.

Tensile strength. There is little variation in the tensile strength values across the window. However, the location of the fracture during testing is also an indicator of weld quality. Ideally, a fracture should occur in the base metal, indicating that the weld is stronger than the base metal. The one set of conditions for which the fracture occurred in the weld for both samples (Figure 6) was the weld made at the highest current, force and time. Thus, the data suggests that avoiding this set of conditions is desirable. The data also indicate that at the highest values of force or time, weld quality may also be somewhat lower (one of the pair tested failed in the weld).

other Measures of Weld Ouality. The recommended set of conditions also gives welds with good bond length, good microstructural integrity, ductile fracture, and tensile strengths greater than the base metal (i.e.. the specimen breaks in the base metal rather than the weld). However, there is little variability across the 
parametric window, and thus little reason to select any particular point.

Relationship Between \& Heat and Maximum Current. As Figure 4 shows, there is considerable variability in the maximum current actually obtained from a given value of the 8 Heat. This indicates that a central value of the maximum current should be set as the target to make allowance for variability in this parameter.

We also recommend that a small number of dummy welds be made prior to the start of $\mathrm{FA}-13$ using the recommended conditions. This will ensure that a $q$ heat value is identified which gives a current of 248 kamps. Without the additional welds, welds may be of somewhat poorer quality than the desired maximum current will produce.

\section{RBFERENGES}

1. Office of Environmental Restoration and Waste Management. Faste Acceptance product speclflcations for Vitrifled High-Level Faste Forms, Revlsion 0, USDOE Document EM-WAPS, U.S. Department of Energy, Germantown, MD (1993), Specification 2.2, Fabrication and closure.

2. B. J. Eberhard, and J. W. Kelker, "High Current Resistance Welding of Nuclear Waste Canisters, "Welding Journal, $61(6), 15-9$ (1982).

(3.) J. W. Kelker, "DWPF Canister Final closure Welding Development, "WSRC-RP-89-693, Revision 1 (1989).

4. DWPF Special Procedure, "Verification of Plug Welder Weld Time," SOP 257-8-2102-T, November 20, 1992 .

5. J. A. Gentilucci, "Technical Issues and SRTC Assistance for Welder Parametric study," OPS-DTF-920046, October 9, 1992.

6. B. J. Eberhard, "DWPF Canister Weld Parametric study Test Completion," Revision 1, SRT-SPS-930084, June 3, 1993.

(7) B. J. Eberhard, "Discontinuance of Bend Test for Parametric Study," SRT-SPS-930128, MaY 27, 1993.

8. S. L. West, W. R. Kanne, Characterization of DWPF Canlster Closure Meld Microstructures, WSRC-TR-94-002, January, 1994.

(9.) 3. R. Harbour, "Selection of Materials for the Ceramic Ring Component of the DWPF Final Weld Plug Assembly, "WSRC-RP-93-54, March 22. 1993. 
FIGURE 1

FORCE, MAXIMUM CURRENT, AND TIMR OF APPLICATION OF CURRENTH FOR WELD PARAYETRIC STUDY

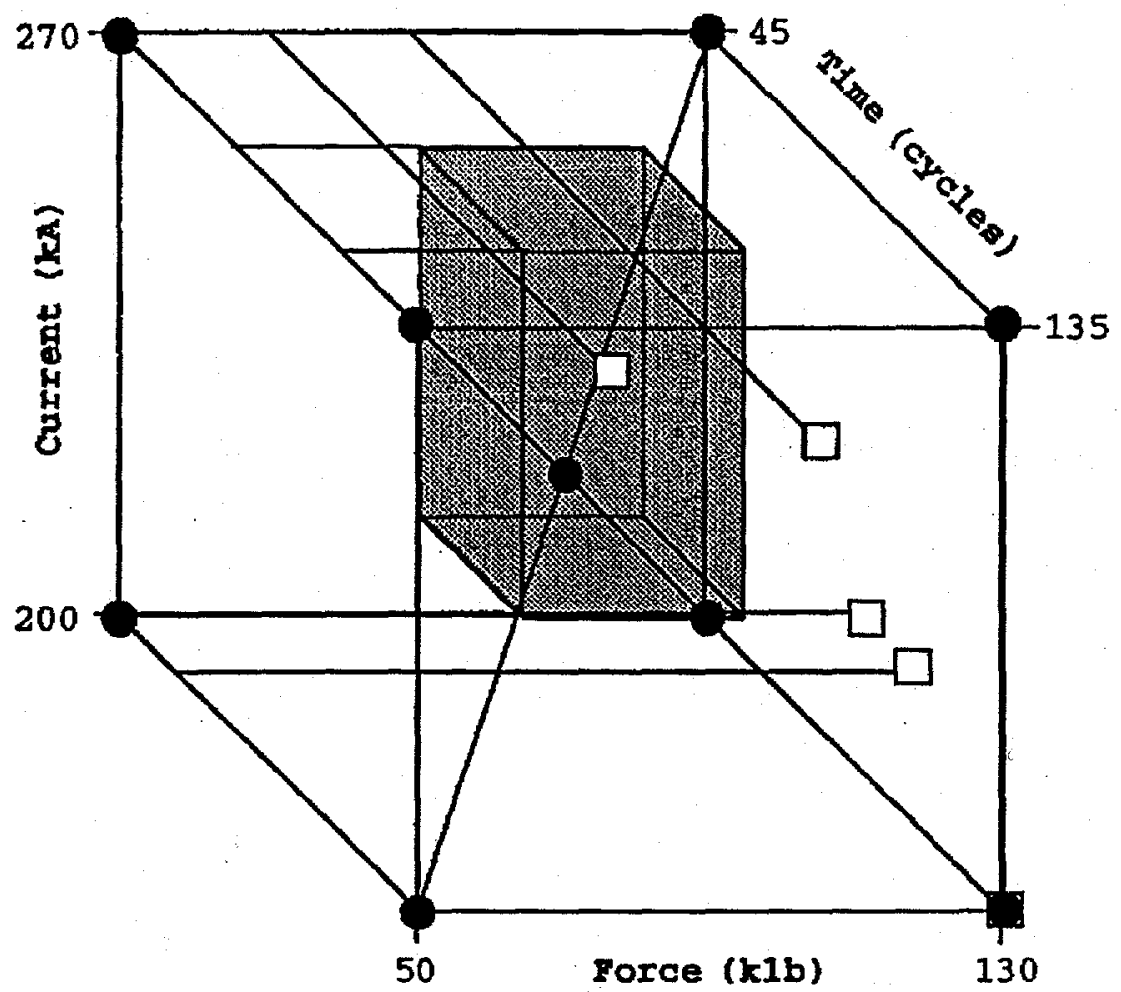

Part A welding conditions

Part B welding conditions

Part $C$ welding conditions (parametric window; individual points not shown. 
FIGURE 2

CALCULATION OF NELD THROAT DISTANCE

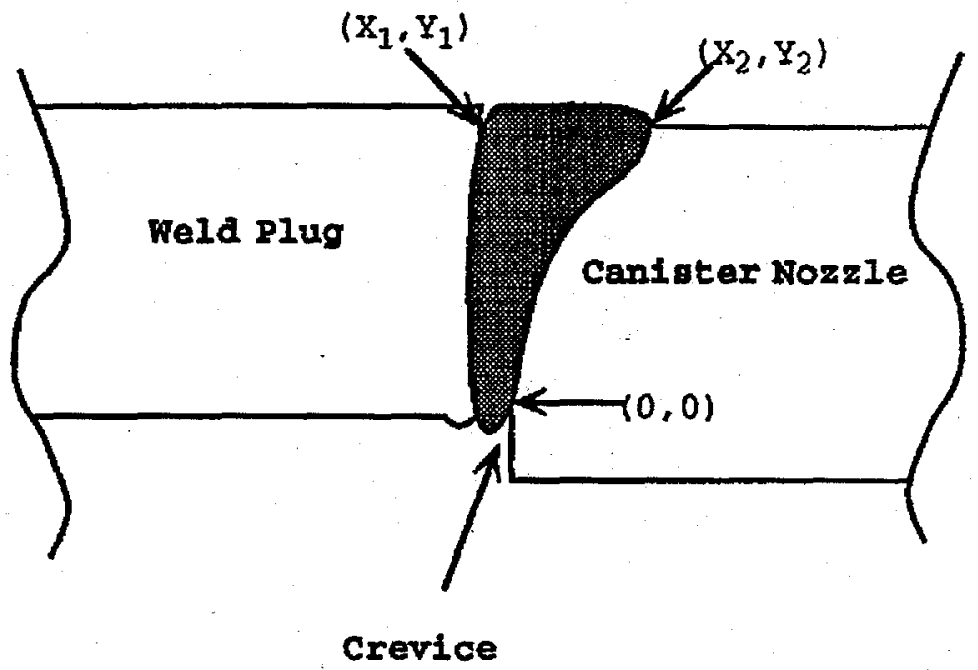

Weld Throat $=\min \left(\sqrt{X_{1}^{2}+Y_{1}^{2}}, \sqrt{X_{2}^{2}+Y_{2}^{2}}\right)$ 
FIGURE 3

\section{DEPENDENCE OF ACTUAL WELD FORCE ON INITIAL AIR PRESSURE}

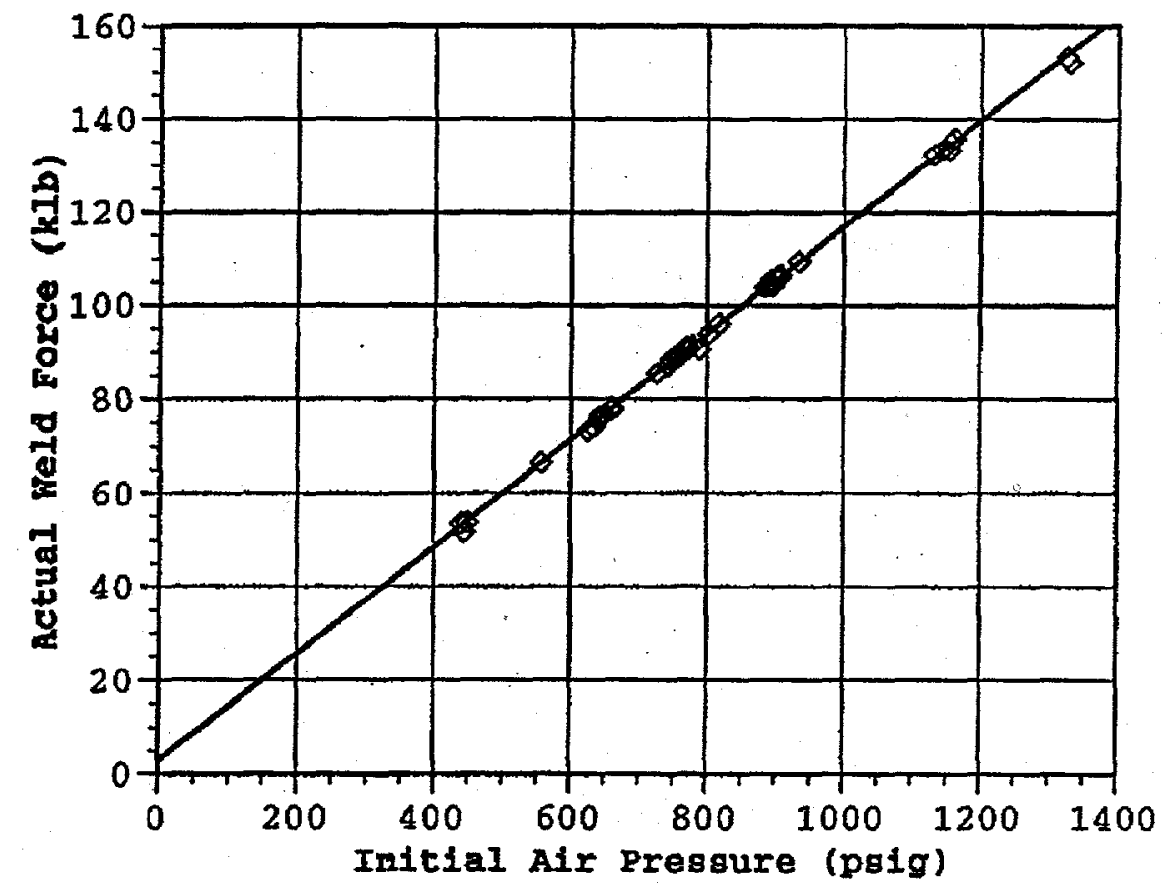

ACTUAL WELD FORCE $=0.1140$ * INITIAL AIR PRESSURE +2.846 $R^{2}=0.9992$ 
FIGURE 4

\section{DEPENDENCE OF ACTUAL MAXIMUM CURBENT ON CURRENT SETTING}

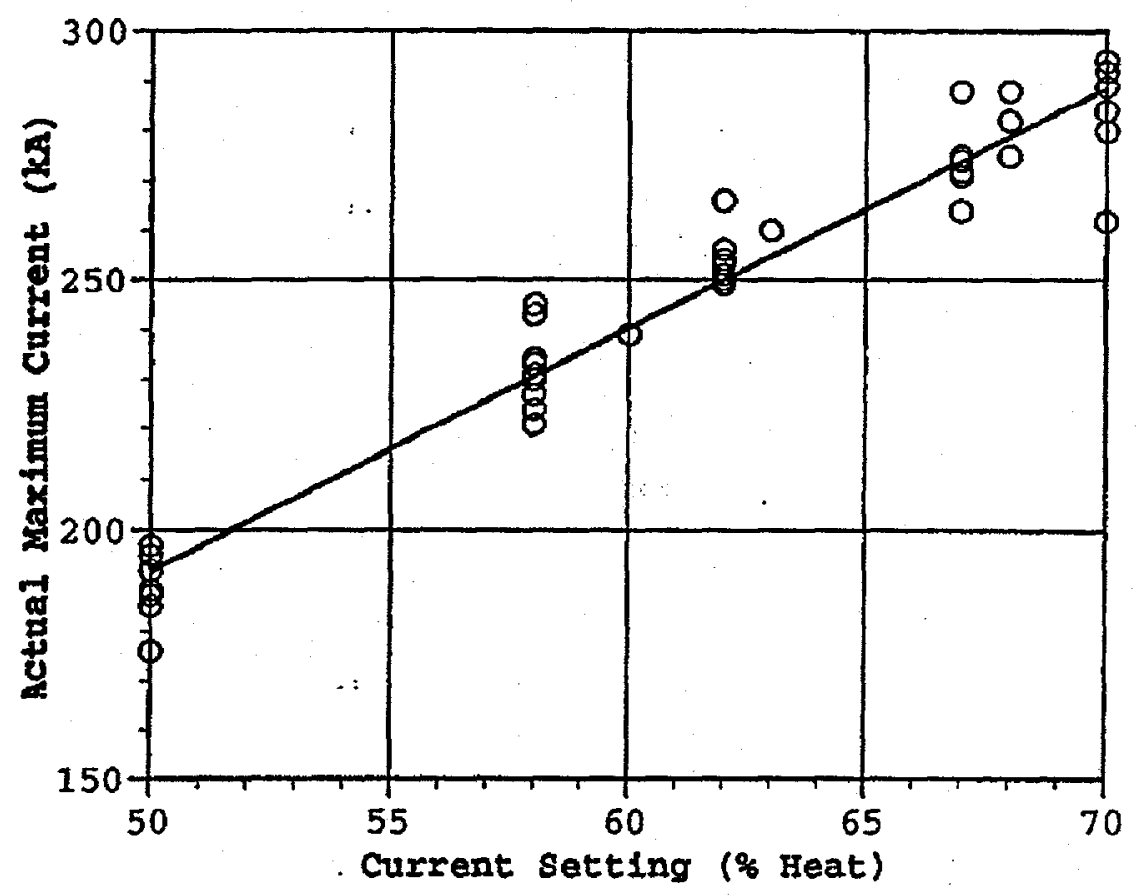

ACTUAL MAXIMUM CURRENT $=4.830 *$ CURRENT SETTING -49.57 $\mathbf{R}^{2}=0.9452$ 
FIGURR 5

BURST STRENCTH OF YIELSS PRODUCED DURTNG PART C TESTING

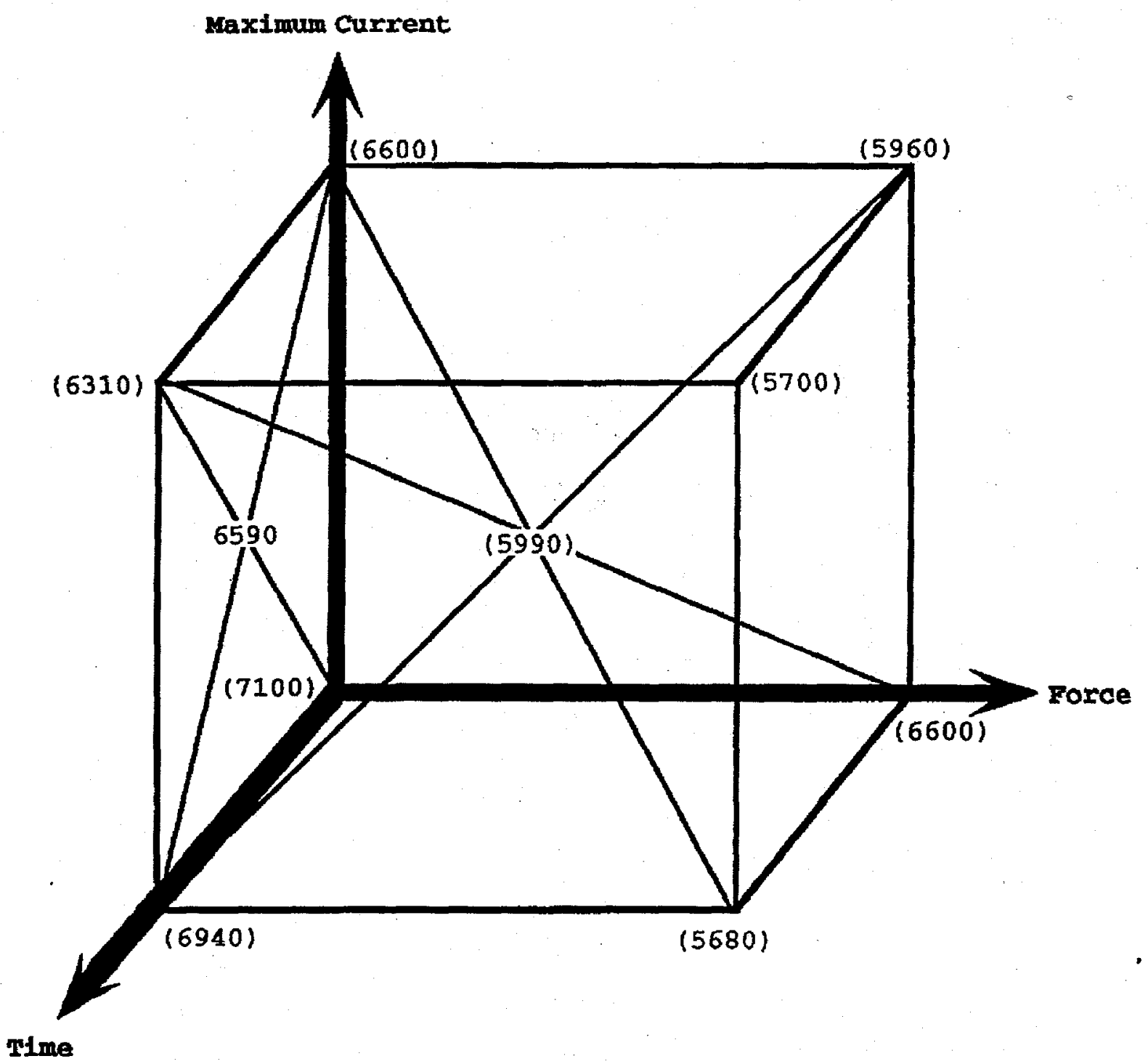


FIGURE 6

POINT OF FAILURE OF WELDS PRODUCED DURING PART C TYESTING

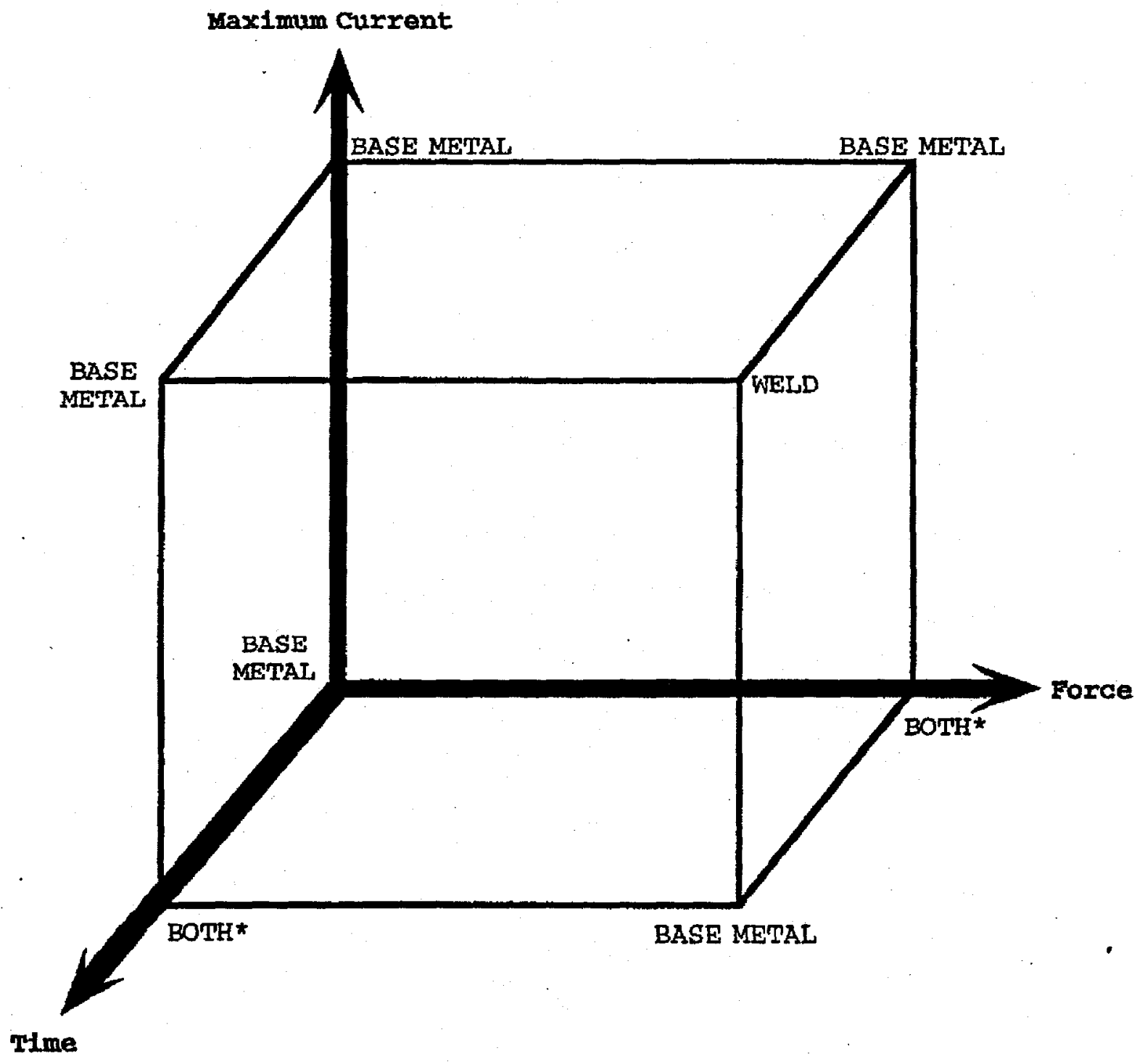

* Duplicate samples tested. One of the pair failed in the weld, and one in the base metal. 
TABLB 1

WEID CONDITIONS FOR PART A OF THE PARAYRTRTC STODY

\begin{tabular}{|c|c|c|c|c|c|}
\hline \multirow[b]{2}{*}{ Weld No. } & \multicolumn{2}{|c|}{ EORCE $(\mathrm{kIb})$} & \multicolumn{2}{|c|}{ CURRENT (KA) } & \multirow{2}{*}{$\begin{array}{c}\text { TIME } \\
\text { (cycles) }\end{array}$} \\
\hline & Taroet & Actual & Target & Actual & \\
\hline KS01 & 130 & 132.4 & 200 & 187 & 45 \\
\hline $\mathrm{KSO} 2$ & 50 & 53.6 & 270 & 284 & 135 \\
\hline $\mathrm{KSO} 3$ & 130 & 135 & 200 & 197 & 135 \\
\hline KS04 & 130 & 136 & 270 & 280 & 45 \\
\hline $\mathrm{KSO} 5$ & 90 & 96.4 & 235 & 239 & 90 \\
\hline KSO6 & 50 & 51.9 & 200 & 176 & 45 \\
\hline RSO7 & 130 & 133.5 & 270 & 292 & 135 \\
\hline KS08 & 50 & 53.7 & 270 & 262 & 45 \\
\hline ksog & 50 & 53.7 & 270 & 185 & 135 \\
\hline
\end{tabular}

TABLE 2

PIFID CONDTILONS ROR PART B OF THR PARAMBTRIC STUDY

\begin{tabular}{|c|c|c|c|c|c|}
\hline \multirow[b]{2}{*}{ Weld No. } & \multicolumn{2}{|c|}{ FORCE $(k l b)$} & \multicolumn{2}{|c|}{ CURRENT (KA) } & \multirow{2}{*}{$\begin{array}{c}\text { TIME } \\
\text { (cycles) }\end{array}$} \\
\hline & Target & Actual & Tarcet & Actual & \\
\hline KS10 & 130 & 133.3 & 200 & 188 & 45 \\
\hline RS11 & 70 & 74.1 & 270 & 289 & 150 \\
\hline KS12 & 150 & 152.3 & 200 & 192 & 45 \\
\hline KS13 & 90 & 94.1 & 270 & 294 & 170 \\
\hline KS14 & 150 & 153.5 & 200 & 195 & 65 \\
\hline
\end{tabular}


TABLE 3

WEIP CONDITIONS FOR RART $C$ CR THE PABAYETRIC STUDY

\begin{tabular}{|c|c|c|c|c|c|}
\hline \multirow[b]{2}{*}{ Weld No. } & \multicolumn{2}{|c|}{ FORCE $(k l b)$} & \multicolumn{2}{|c|}{ CURRENT (kA) } & \multirow{2}{*}{$\begin{array}{c}\text { TIME } \\
\text { (cycles) }\end{array}$} \\
\hline & Taroet & Actual & Target & Actual & \\
\hline KS15 & 75 & 76.5 & 226 & 221 & 80 \\
\hline KS16 & 105 & 105.5 & 270 & 275 & 110 \\
\hline $\mathrm{KS} 17$ & 75 & 76.5 & 226 & 243 & 110 \\
\hline $\mathrm{KS} 18$ & 75 & 76.5 & 270 & 275 & 80 \\
\hline KS19 & 90 & 85.6 & 248 & 260 & 95 \\
\hline $\mathrm{KS2O}$ & 105 & 106.4 & 226 & 230 & 80 \\
\hline KS21 & 75 & 76.5 & 270 & 282 & 110 \\
\hline KS22 & 105 & 106.7 & 270 & 288 & 80 \\
\hline $\mathrm{KS} 23$ & 105 & 109.6 & 226 & 233 & 110 \\
\hline $\mathrm{KS} 24$ & 90 & 89.4 & 248 & 251 & 110 \\
\hline $\mathrm{KS} 25$ & 75 & 76.8 & 248 & 251 & 95 \\
\hline $\mathrm{KS} 26$ & 90 & 91.4 & 226 & 245 & 95 \\
\hline KS27 & 90 & 89.1 & 270 & 274 & 95 \\
\hline $\mathrm{KS} 28$ & 90 & 90.8 & 248 & 253 & 80 \\
\hline Ks29 & 105 & 104.6 & 248 & 251 & 95 \\
\hline KS3O & 90 & 89.1 & 248 & 256 & 95 \\
\hline KS31 & 90 & 91.7 & 248 & 254 & 95 \\
\hline KS32 & 90 & 89.3 & 248 & 251 & 110 \\
\hline KS33 & 75 & 73.4 & 226 & 231 & 110 \\
\hline KS34 & 75 & 77.7 & 248 & 250 & 95 \\
\hline KS35 & 105 & 104.3 & 270 & 272 & 80 \\
\hline KS36 & 90 & 87.3 & 226 & 227 & 95 \\
\hline KS37 & 105 & 104.3 & 226 & 234 & 80 \\
\hline KS38 & 105 & 104 & 226 & 230 & 110 \\
\hline KS39 & 90 & 78.3 & 270 & 264 & 95 \\
\hline KS39A & 90 & 88.5 & 270 & 271 & 95 \\
\hline $\mathrm{KS} 40$ & 75 & 66.5 & 270 & 272 & 80 \\
\hline XS40A & 75 & 77.1 & 270 & 271 & 80 \\
\hline KS41 & 75 & 75.5 & 226 & 224 & 80 \\
\hline$K S 42$ & 105 & 106 & 270 & 288 & 110 \\
\hline $\mathrm{KS} 43$ & 90 & 90.6 & 248 & 249 & 80 \\
\hline $\mathrm{KS} 44$ & 75 & 74.3 & 270 & 275 & 110 \\
\hline KS45 & 105 & 105.8 & 248 & 254 & 95 \\
\hline KS46 & 90 & 90.8 & 248 & 266 & 95 \\
\hline
\end{tabular}


TABLE 4

\section{RESULTS OF PART A OF TAE PARAMETRIC STUDY*}

\begin{tabular}{|c|c|c|c|c|c|}
\hline Weld No. & $\begin{array}{l}\text { Plua } \\
\text { Height } \\
\text { (mil) }\end{array}$ & $\begin{array}{l}\text { Leak_Rate } \\
\text { (cc-atm } \\
\text { He/secl }\end{array}$ & 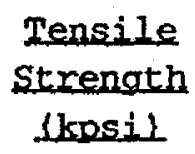 & Bend Test & $\frac{\text { Weld }}{\text { Throat }} \frac{\text { (mil) }}{\text { (mil }}$ \\
\hline $\mathrm{KSO} 1$ & 272 & $<9.30 \mathrm{e}-10$ & 74.0 & Fall Both & 266 \\
\hline $\mathrm{KSO} 2$ & 46 & $<9.66 \mathrm{e}-10$ & 85.0 & Pass Both & 294 \\
\hline $\mathrm{KSO3}$ & 65 & $<9.79 \mathrm{e}-10$ & 84.0 & Fal1, Pass & 397 \\
\hline KSO4 & 57 & $<1.00 \mathrm{e}-9$ & 84.0 & Fail, Paga & 382 \\
\hline KS05 & 75 & $<9.30 \mathrm{e}-10$ & 83.3 & Fa11 Both & 396 \\
\hline KS06 & 326 & $<9.48 \mathrm{e}-10$ & 70.2 & Fall Both & 218 \\
\hline KS07 & 28 & $<9.20 \mathrm{e}-10$ & 80.0 & Pass Both & 391 \\
\hline $\mathrm{KSO} 8$ & 139 & $<8.51 \mathrm{e}-10$ & 73.1 & Fa11, Pass & 340 \\
\hline KS09 & 90 & $<8.61 e-10$ & 83.4 & Fail, Pass & 394 \\
\hline
\end{tabular}

TABLE 5

REQUTWS OF PART B OF THE PARAYRTRIC STUDY*

\begin{tabular}{|c|c|c|c|}
\hline & Plug Height & Leak_ $\mathrm{F}$ & at strer \\
\hline Weid Ne. & (mil) & He(sec) & (osig) \\
\hline KS10 & 267 & $<9.88 \mathrm{e}-10$ & 1000 \\
\hline KS11 & 45 & $<1.61 \mathrm{e}-9$ & 5000 \\
\hline KS12 & 271 & $<9.80 \mathrm{e}-10$ & 490 \\
\hline KS13 & 46 & $<9.30 \mathrm{e}-10$ & 6650 \\
\hline KS14 & 158 & $<9.68 \mathrm{e}-10$ & 2250 \\
\hline
\end{tabular}


TABLE 6 RESULTS OF PART C OF THE PARAMETRIC STUDY*

\begin{tabular}{|c|c|c|c|c|c|}
\hline Weld Noe & $\begin{array}{l}\text { Plug } \\
\text { Height } \\
\text { (mil) }\end{array}$ & $\begin{array}{l}\text { Leak Rate } \\
\text { (cc-atm } \\
\text { He/sec) }\end{array}$ & $\begin{array}{l}\text { Burst } \\
\text { Strength } \\
\text { (osial }\end{array}$ & $\frac{\text { Tensile }}{\text { Strength }} \frac{\text { (kosi) }}{\text { (kosil }}$ & $\begin{array}{l}\text { Weld } \\
\text { Throat } \\
\text { (mill }\end{array}$ \\
\hline KS15 & 88 & $<8.30 \mathrm{e}-10$ & 7100 & $\mathrm{NA}$ & $\mathrm{NA}$ \\
\hline KS16 & 55 & $<9.78 \mathrm{e}-10$ & 5700 & $\mathrm{NA}$ & $\mathrm{NA}$ \\
\hline KS17 & 79 & $<1.25 \mathrm{e}-9$ & 6940 & $\mathrm{NA}$ & NA \\
\hline KS18 & 62 & $<8.85 e-10$ & 6600 & $\mathrm{NA}$ & $\mathrm{NA}$ \\
\hline KS19 & 70 & $<8.81 e-10$ & NA & $\mathrm{NA}$ & 395 \\
\hline KS20 & 84 & $<7.73 \mathrm{e}-10$ & 6600 & NA & $\mathrm{NA}$ \\
\hline KS21 & 53 & $<9.63 \mathrm{e}-10$ & 6310 & NA & NA \\
\hline $\mathrm{KS} 22$ & 68 & $<1.07 \mathrm{e}-9$ & 5960 & NA & NA \\
\hline KS23 & 73 & $<9.93 e-10$ & 5680 & $\mathrm{NA}$ & $\mathrm{NA}$ \\
\hline KS24 & 66 & $<2.98 e-10$ & NA. & $\mathrm{NA}$ & 399 \\
\hline KS25 & 71 & $<5.30 \mathrm{e}-10$ & 6590 & $\mathrm{NA}$ & $\mathrm{NA}$ \\
\hline KS26 & 74 & $<8.40 e-10$ & $\mathrm{NA}$ & $\mathrm{NA}$ & 397 \\
\hline KS27 & 55 & $<9.35 e-10$ & NA & NA & 401 \\
\hline $\mathrm{KS} 28$ & 77 & $<9.28 e-10$ & NA & NA & 393 \\
\hline KS29 & 67 & $<9.08 e-10$ & $N A$ & NA & 393 \\
\hline KS30 & 76 & $<1.04 e-9$ & 5990 & NA & $\mathrm{NA}$ \\
\hline KS31 & 71 & $<8.21 e-10$ & $\mathrm{NA}$ & 85 & 399 \\
\hline KS32 & 72 & $<9.31 \mathrm{e}-10$ & NA & NA & 396 \\
\hline Rs33 & 78 & $<9.11 e-10$ & NA & 85 & 400 \\
\hline KS34 & 74 & $<9.03 e-10$ & NA & $\mathrm{NA}$ & 391 \\
\hline KS35 & 72 & $<9.01 e-10$ & NA & 86 & 403 \\
\hline ks3 6 & 82 & $<9.14 \mathrm{e}-10$ & NA & NA & 404 \\
\hline KS37 & 86 & $<9.16 e-10$ & NA & 86 & 404 \\
\hline KS38 & 74 & $<9.10 \mathrm{e}-10$ & $\mathrm{NA}$ & 85 & 398 \\
\hline KS39 & 61 & $<9.07 e-10$ & NA & NA & 427 \\
\hline KS39A & 59 & $<3.37 \mathrm{e}-9$ & NA & NA & 398 \\
\hline KS40 & 64 & $<9.22 \mathrm{e}-10$ & NA & 83 & 408 \\
\hline KS40A & 66 & $<1.00 \mathrm{e}-9$ & NA & 85 & 398 \\
\hline KS41 & 92 & $<9.22 \mathrm{e}-10$ & NA & 85 & 376 \\
\hline KS42 & 53 & $<9.32 \mathrm{e}-10$ & NA & 81 & 394 \\
\hline KS43 & 77 & $<9.05 e-10$ & NA & $\mathrm{NA}$ & 401 \\
\hline KS44 & 45 & $<9.00 \mathrm{e}-10$ & $\mathbf{N A}$ & 84 & 402 \\
\hline $\mathrm{KS} 45$ & 69 & $<9.30 e-10$ & NA & $\mathrm{NA}$ & 407 \\
\hline KS46 & 69 & $<9.28 \mathrm{e}-10$ & $\mathrm{NA}$ & $\mathrm{NA}$ & 398 \\
\hline
\end{tabular}


TABLE 7

WBID CONDITIONS FOR CERAMTC RING STUDY

$\begin{array}{cccc}\text { Weld No. } & \begin{array}{c}\text { Initial } \\ \text { Eorce }(\mathrm{kIb})\end{array} & \begin{array}{c}\text { Maximum } \\ \text { cumrent (kA) }\end{array} & \begin{array}{c}\text { Time } \\ \text { (crcles) }\end{array} \\ \text { CER 1 } & 80.6 & 240 & 90 \\ \text { CER 2 } & 80.9 & 239 & 90 \\ \text { CER 3 } & 81.8 & 240 & 90 \\ \text { CER 4 } & 80.9 & 239 & 90 \\ \text { CER 5 } & 81.2 & 246 & 90 \\ \text { CER 6 } & 81.2 & 240 & 90 \\ \text { CER 7 } & 80.9 & 248 & 90\end{array}$

TABLE 8

RESULTS OF CERAMIC RTME STODY*

\begin{tabular}{|c|c|c|c|c|c|}
\hline Weld Noc & $\begin{array}{l}\text { Plug } \\
\text { Height } \\
\text { (mil) }\end{array}$ & $\begin{array}{c}\text { Lieak } \\
\text { Rate (ce- } \\
\text { atm } \\
\text { He/secl }\end{array}$ & $\begin{array}{l}\text { Burst } \\
\text { strenath } \\
\text { (nsia) }\end{array}$ & $\begin{array}{l}\frac{\text { Tensile }}{\text { Strength }} \\
\text { (kpsi) }\end{array}$ & $\begin{array}{l}\text { Weld } \\
\text { Throat } \\
\text { Imill }\end{array}$ \\
\hline CER 1 & 84 & $<1.0 e^{-9}$ & 7200 & NA & NA \\
\hline CER 2 & 80 & $<7.2 \mathrm{e}-10$ & NA & 85,78 & 384 \\
\hline CER 3 & 80 & $<1.0 \mathrm{e}-9$ & 7500 & NA & NA \\
\hline CER 4 & 81 & $<2.0 e-9$ & NA & 80,80 & 396 \\
\hline CER 5 & 81 & $<2.0 e-9$ & 7300 & NA & NA \\
\hline CER 6 & 82 & $<1.0 \mathrm{e}-9$ & NA & 78,78 & 405 \\
\hline CER 7 & 80 & $<1.0 \mathrm{e}-9$ & 6500 & NA & NA \\
\hline
\end{tabular}

